\title{
Determination of the Nutritional Value of Diet Containing Bacillus subtilis Hydrolyzed Feather Meal in Adult Dogs
}

\author{
Geruza Silveira Machado ${ }^{1}$, Ana Paula Folmer Correa ${ }^{2}$, Paula Gabriela da Silva Pires ${ }^{1}$, Letícia Marconatto ${ }^{3}$, \\ Adriano Brandelli ${ }^{4}\left(\mathbb{D}\right.$, Alexandre de Mello Kessler $^{1}$ and Luciano Trevizan ${ }^{1, *} \mathbb{C}$ \\ 1 Programa de Pós-Graduação em Zootecnia, Universidade Federal do Rio Grande do Sul, Porto \\ Alegre 91540-000, RS, Brazil; gsm_sg@hotmail.com (G.S.M.); paulagabrielapires@yahoo.com.br (P.G.d.S.P.); \\ akessler@ufrgs.br (A.d.M.K.) \\ 2 Programa de Pós-Graduação em Recursos Naturais, Universidade Federal de Roraima, \\ Boa Vista 69304-000, RR, Brazil; folmercorrea@gmail.com \\ 3 Instituto do Petróleo e dos Recursos Naturais, Pontifícia Universidade Católica do Rio Grande do Sul, \\ Porto Alegre 90160-091, RS, Brazil; leticiamarconatto@gmail.com \\ 4 Programa de Pós-Graduação em Ciência e Tecnologia de Alimentos, Universidade Federal do Rio Grande do Sul, \\ Porto Alegre 91509-900, RS, Brazil; abrand@ufrgs.br \\ * Correspondence: 1trevizan@ufrgs.br; Tel.: +55-51-3308-6590
}

check for

updates

Citation: Machado, G.S.; Correa, A.P.F.; Pires, P.G.d.S.; Marconatto, L.; Brandelli, A.; Kessler, A.d.M.; Trevizan, L. Determination of the Nutritional Value of Diet Containing Bacillus subtilis Hydrolyzed Feather Meal in Adult Dogs. Animals 2021, 11, 3553. https://doi.org/10.3390/ ani11123553

Academic Editor: Anshan Shan

Received: 5 November 2021

Accepted: 12 December 2021

Published: 14 December 2021

Publisher's Note: MDPI stays neutral with regard to jurisdictional claims in published maps and institutional affiliations.

Copyright: (c) 2021 by the authors. Licensee MDPI, Basel, Switzerland. This article is an open access article distributed under the terms and conditions of the Creative Commons Attribution (CC BY) license (https:// creativecommons.org/licenses/by/ $4.0 /)$.
Simple Summary: The production of meat for human consumption produces extra ingredients used in animal nutrition. Feathers, for example, account for about $7 \%$ of the chicken's body weight. When discarded, it presents a potential risk of environmental contamination. Feathers are minimally digested in mammals and are a very rich source of protein. Improved digestibility can be done by thermal processing or by microorganisms. Bacillus subtilis was shown to have great feather-degrading activity In vitro and we produced an amount of microbial hydrolysate to test in dogs. We did some evaluations on the ingredient to measure the effects of the microorganism on feathers. In dogs, a test of total tract digestibility, microbial resistance to the gastrointestinal tract, and fecal characteristics were performed. Bacillus subtilis was less efficient to digest feathers when a higher concentration of feathers was added to the culture. The amino acid profile in feathers has probably changed due to fermentation. Dogs ate the diets quickly, with no refusals. Nutrient and energy total tract digestibility were lower when compared to thermally processed feathers, but Bacillus subtilis was found viable in the feces of dogs that ingested fermented feathers, signaling that Bacillus subtilis is resistant to digestion and may bring some probiotic effect.

Abstract: Feathers are naturally made up of non-digestible proteins. Under thermal processing, total tract digestibility can be partially improved. Furthermore, Bacillus subtilis (Bs) has shown a hydrolytic effect In vitro. Then, a Bs FTC01 was selected to hydrolyze enough feathers to produce a meal, and then test the quality and inclusion in the dog's diet to measure the apparent total tract digestibility coefficient (ATTDC) in vivo and the microorganism's ability to survive in the gastrointestinal tract. A basal diet was added with $9.09 \%$ hydrolyzed Bs feather meal (HFMBs) or 9.09\% thermally hydrolyzed feather meal (HFMT). Nine adult dogs were randomized into two 10-day blocks and fed different diets. Microbial counts were performed on feather meal, diets and feces. The Bs was less effective in digesting the feathers, which reduced the ATTDC of dry matter, crude protein, energy and increased the production of fecal DM, but the fecal score was maintained $(p>0.05)$. The digestible energy of HFMT and HFMBs was 18,590 J/kg and $9196 \mathrm{~J} / \mathrm{kg}$, respectively. Bacillus subtilis showed limitation to digest feather in large scale, but the resistance of Bs to digestion was observed since it grown on feces culture.

Keywords: feather processing; total tract digestibility; hydrolyzed protein; poultry byproduct 


\section{Introduction}

In poultry production, feathers are considered a by-product of slaughterhouses and correspond to about 7\% of the bird's body weight [1]. According to FAO [2], a total of 114,267 thousand tons of broiler chicken meat was produced in the world, and estimated feather production was close to 8000 thousand tons in the same year. In the industry, feathers are transformed into hydrolyzed feather meal, through digestion by thermal processing, with high pressure and temperature, generating an ingredient with high protein concentration. Feather meal normally contains more than $85 \%$ of crude protein in dry matter, mostly from keratin, the main constituent of the feather. However, the method is not satisfactory, since the in vivo total tract digestibility of feather protein is relatively low, around $60 \%[3,4]$. Specifically, low total tract digestibility values of about $67 \%$ have been reported in dogs [5].

The use of proteolytic microorganisms for feather hydrolysis can be an alternative to the traditional method, since its effect on nutrient availability is real. According to Cedrola [6], the biodegradation of keratin by microorganism represents an alternative method to improve the nutritional value of feathers, improving the quality of the protein that has low total tract digestibility, even if there is loss of nutrients during the fermentation. The increased availability of amino acid (AA) improves the ingredient value and permit incorporation in diets for different species in greater proportion, especially as a source of sulfur AA. Another important factor to be considered is the low molecular weight acquired by the soluble portions of the feather meal processed by heat and pressure [5]. The association between microorganisms and thermal processing can improve the availability of AA, once more. Currently, protein ingredients with such characteristics have potential use in hypoallergenic diets for dogs and cats, a category of pet food in high demand [7,8].

Another interesting point is the accumulation of microorganisms in the feather meal after processing, when beneficial microbes are used for hydrolysis. Some strains of Bacillus spp. are recognized as feather-degrading bacteria and to exert beneficial effects on the host health after oral administration $[9,10]$. The sporulated forms has the ability to resist the low stomach $\mathrm{pH}$ and can reach the intestine in large quantities, where they can produce competitive exclusion with non-desired bacteria which is known as a probiotic effect [11]. The aim of the present study was to compare the thermally hydrolyzed feather meal with Bacillus subtilis hydrolyzed feather meal to determine the quality of the ingredient and total tract digestibility of nutrients and energy in diets for adult dogs. In addition, the research seeks to highlight the potential of B. subtilis resisting to digestion, then it could be studied as a probiotic agent in dogs.

\section{Materials and Methods}

All animal care and handling procedures were approved by the Institutional Animal Care and Use Committee at the Universidade Federal do Rio Grande do Sul, protocol number 20643.

\subsection{Animals}

Nine healthy adult Beagle, coming from Animal Science Department, Universidade Federal do Rio Grande do Sul, Porto Alegre, Brazil, were used in this study. They were all intact, between 2 and 3 years old, weighing $11.3 \pm 1.60 \mathrm{~kg}$, and free of endo and ectoparasites. All dogs were regularly immunized and submitted to clinical and laboratory tests to measure complete blood count $(\mathrm{CBC})$ and to perform biochemical and coproparasitological analyses before starting the study. The dogs were housed in individual stainles steel metabolic cages $(1.0 \mathrm{~m} \times 1.0 \mathrm{~m} \times 1.5 \mathrm{~m})$ equipped with a feces and urine collector, feeders, and drinkers in a controlled room at $25^{\circ} \mathrm{C}$, with a light dark cycle of $14 \mathrm{~h}: 10 \mathrm{~h}$.

\subsection{Diets}

Two feather meals were produced to compare the thermal and microbial fermentation on feather degradation and nutrient availability (Table 2). 
The experimental diets were produced from an extruded basal diet, formulated to meet the energy and nutrient requirement of adult dog, as recommended by the FEDIAF [12]. Basal diet was replaced with $9.09 \%$ B. subtilis hydrolyzed feather meal or $9.09 \%$ thermally hydrolyzed feather meal to composed the treatments (Table 1).

Table 1. Ingredients and chemical composition of experimental diets containing $9.09 \%$ feather meal hydrolyzed by Bacillus subtilis (HFMBs) and 9.09\% thermal feather meal (HFMT).

\begin{tabular}{cccc}
\hline & & Treatments & \\
\cline { 2 - 4 } & BD $^{\mathbf{1}}$ & BD + HFMBs $^{\mathbf{2}}$ & BD + HFMT $^{\mathbf{3}}$ \\
\hline Ingredients (g/kg) & 100 & 100 & 100 \\
Basal diet & 0 & 10 & 0 \\
HFMBs & 0 & 0 & 10 \\
HFMT & & & 964 \\
Chemical composition & 967 & 964 & 82 \\
(g/kg) & 88 & 83 & 326 \\
Dry matter & 271 & 327 & 126 \\
Mineral matter & 130 & 124 & 47 \\
Crude protein & 52 & 47 & 20,735 \\
Ether extract & 20,359 & 20,602 & \\
Crude fiber & & & \\
Gross energy, J/kg & & & \\
\hline
\end{tabular}

${ }^{1}$ Basal diet (BD) - Ingredients of $1000 \mathrm{~kg}$ basal diet: rice grains (244.8 kg); rice brains (229.2 kg); corn (156.3 kg); bovine meat and bone meal (130.2 kg); poultry viscera meal (125.0 kg); wheat bran (104.2 kg); sodium chloride (5.2 g); premix mineral/vitamins (4.2 kg)_adding per kg of diet: Vitamin A. $7000 \mathrm{IU}$; Vitamin B1. $2 \mathrm{mg}$; Vitamin B12. $25 \mathrm{mcg}$; Vitamin B2. 4 mg; Vitamin B6. 2 mg; Vitamin D3. 600 IU; Vitamin E. 50 IU; Vitamin K3. $1 \mathrm{mg}$; Folic Acid. 0.2 mg; Pantothenic Acid. 10 mg; Biotin. 0.03 mg; Niacin. 30 mg; Cobalt. 10 mg; Copper. 7 mg; Iron. 80 mg; Iodine. 1.5 mg; Manganese. 5 mg; Selenium. 0.2 mg; Zinc. 100 mg; Antioxidant (BHT). 150 mg; yucca (0.3); caramel colorant (0.5). ${ }^{2} \mathrm{DB}+$ HFMBs = basal diet added by $9.09 \%$ feather meal hydrolyzed by Bacillus subtilis; ${ }^{3} \mathrm{DB}+\mathrm{HFMT}=\mathrm{basal}$ diet added by $9.09 \%$ thermal hydrolyzed feather meal.

Table 2. Chemical composition and amino acid profile of hydrolyzed feather meal by Bacillus subtilis (HFMBs) and thermally hydrolyzed feather meal (HFMT) expressed in dry matter basis.

\begin{tabular}{|c|c|c|}
\hline Itens, \% DM Basis & HFMBs (\%) & HFMT (\%) \\
\hline Dry matter & 93.6 & 93.7 \\
\hline Crude protein & 88.3 & 84.1 \\
\hline Fat & 6.80 & 8.30 \\
\hline Mineral matter & 3.20 & 2.90 \\
\hline Gross energy, J/kg & 23,033 & 24,552 \\
\hline \multicolumn{3}{|c|}{ Amino acids profile, $\%$} \\
\hline Aspartic acid ${ }^{1}$ & 6.95 & 6.23 \\
\hline Glutamic acid $^{1}$ & 10.8 & 9.06 \\
\hline Serine ${ }^{1}$ & 10.2 & 10.9 \\
\hline Glycine $^{1}$ & 7.62 & 6.47 \\
\hline Histidine $^{1}$ & 0.85 & 0.41 \\
\hline Arginine ${ }^{1}$ & 6.25 & 5.67 \\
\hline Threonine $^{1}$ & 3.93 & 3.99 \\
\hline Alanine ${ }^{1}$ & 4.01 & 3.57 \\
\hline Proline ${ }^{1}$ & 8.44 & 9.87 \\
\hline Tyrosine ${ }^{1}$ & 2.43 & 2.11 \\
\hline Valine ${ }^{1}$ & 6.12 & 6.58 \\
\hline Methionine $^{1}$ & 1,53 & 2.41 \\
\hline Cystine $^{1}$ & 3.38 & 8.11 \\
\hline Isoleucine ${ }^{1}$ & 4.10 & 4.29 \\
\hline Leucine $^{1}$ & 7.31 & 6.98 \\
\hline Phenylalanine ${ }^{1}$ & 4.25 & 4.39 \\
\hline Lysine $^{1}$ & 2.43 & 1.14 \\
\hline Tryptophane 2 & 0.40 & 0.19 \\
\hline Total aas & 91.0 & 92.4 \\
\hline
\end{tabular}

${ }^{1}$ HPLC, according to White et al. [13] and Hagen et al. [14]. ${ }^{2}$ Hydrolysis and determination, according Lucas \& Sotelo [15].

\subsubsection{Thermally Hydrolyzed Feather Meal (HFMT)}

Thermal hydrolysis was used to produce HFMT in an industrial plant. Feathers from the slaughterhouse were visually inspected upon discharge and then received the first 
addition of antioxidant to protect the raw material during thermal hydrolysis. The process consists of a temperature ramp from $110^{\circ} \mathrm{C}$ to $170{ }^{\circ} \mathrm{C}$ during $20 \mathrm{~min}$, reaching $303.9 \mathrm{kPa}$ pressure (Kabsa Exportadora S.A., Porto Alegre, RS, Brazil). The product was discharged into the continuous flow dryer where it remained for $30 \mathrm{~min}$. The product was maintained at $110^{\circ} \mathrm{C}$ with a gradual drop to $50^{\circ} \mathrm{C}$. After drying, the feathers were sieved, ground, and received an additional antioxidant addition before being bagged. The production was monitored and about $50 \mathrm{~kg}$ of the meal originated from the same batch was separated to carry out the evaluation.

\subsubsection{Bacillus Subtilis Hydrolyzed Feather Meal (HFMBs)}

HFMBs was produced in the laboratory. The B. subtilis FTC01(9) strain used in the study was multiplied to form the pre-inoculum in brain heart infusion broth (BHI; Himedia, Mumbai, India) incubated for $24 \mathrm{~h}$ at $37^{\circ} \mathrm{C}$, with agitation of $120 \mathrm{rpm}$. The pre-inoculum was added to a broth $\left(0.5 \mathrm{~g} / \mathrm{L} \mathrm{NaCl}, 0.3 \mathrm{~g} / \mathrm{L} \mathrm{K}_{2} \mathrm{HPO}_{4}, 0.4 \mathrm{~g} / \mathrm{L} \mathrm{KH}_{2} \mathrm{PO}_{4}\right)$ containing $10 \%$ $(w / v)$ feathers, and incubated in a bioreactor with agitation at $70 \mathrm{rpm}$ at $37^{\circ} \mathrm{C}$, for $120 \mathrm{~h}$. Then, the digested product was placed in plastic forms composing a $2 \mathrm{~cm}$ deep film, and submitted to drying in a forced air oven at $55^{\circ} \mathrm{C}$ for $72 \mathrm{~h}$. The dried material was ground through a 1-mm screen in a Wiley mill (DeLeo Equipamentos Laboratoriais, Porto Alegre, Brazil). Five baths in a bioreactor were made to achieve the mass of hydrolyzed feathers sufficient to make the meal necessary to carry out in vivo evaluation. At the end, all baths were homogenized to form a single meal.

\section{Evaluations on the Feather Processing}

Degradation Factor

Feathers processed by microorganisms were subjected to degradation factor assessment. The material was filtered through a $2.5 \mathrm{~mm}$ screen filter and the non-degraded feather residues were washed with distilled water, dried in an oven, and weighed. This factor aims to estimate the degree of degradation from the original content according to the following formula:

$$
\text { Degradation factor }=[(\text { initial feather mass }- \text { final feather mass }) /(\text { initial feather mass })]
$$

\section{Ultrastructural Evaluation of Feathers}

To verify the action of the processing on the structure of the feathers, samples of the feathers in natura and the processed meal were analyzed by scanning electron microscopy. The samples were mounted on a stub, coated with gold-palladium of $35 \mathrm{~nm}$ for $3 \mathrm{~min}$ (Sputter Coater-SCD 050 Balzers, Germany), and analyzed through a scanning electron microscope (JEOL 6060, Tokyo, Japan) at a standard magnification of 500 $\times$. The integrity of the structure of the thermally processed feathers and those processed by microorganisms were observed.

\section{Aminograms and Protein Efficiency Ratio (PER)}

The aminograms were performed using high performance liquid chromatography (HPLC) following the methodology described by White et al. [13] and Hagen et al. [14]. Tryptophan was analyzed according to the methodology described by Lucas \& Sotelo [15]. The protein efficiency ratio value was calculated and compared with in natura feather, from the composition of the AAs found in the aminograms, based on an equations developed by Alsmeyer, Cunningham \& Happich [16], as follow:

$$
\mathrm{PER}=-1.816+0.435 \text { (methionine) }+0.780 \text { (leucine) }+0.211 \text { (histidine) }-0.944 \text { (tyrosine) }
$$

\section{Microbial Count (Colony Forming Unit-CFU)}

The counting of microorganisms was performed by the surface counting technique, after addition of $25 \mathrm{~g}$ feather meal in $225 \mathrm{~mL}$ of saline solution $(\mathrm{NaCl}, 0.85 \% \mathrm{w} / \mathrm{v})$, followed by serial dilutions, adding $1 \mathrm{~mL}$ of each dilution into tubes containing $9 \mathrm{~mL}$ of saline solution. An aliquot of each dilution $(0.1 \mathrm{~mL})$ was transferred to Petri dishes containing Nutrient Agar (20 g/L agar-agar and $13 \mathrm{~g} / \mathrm{L}$ Nutrient Broth) as culture medium. Subse- 
quently, the aliquot was spread over the medium with the aid of a Drigalsky loop until the aliquot was completely adsorbed onto the medium. The Petri dishes were incubated at $37^{\circ} \mathrm{C}$ for $24 \mathrm{~h}$. Colonies were identified by morphology and counted.

\subsection{Experimental Diets and Feed Management}

The experimental diets were prepared using a basal diet (BD) that was added with $9.09 \%(w / w)$ HFMBs or $9.09 \%(w / w)$ HFMT according to the methodology described by Adeola [17]. The feather meal was added over the diet directly in the feeders, previous to offer to the dogs. Three treatments were acquired: BD, BD + HFMBs (9.09\%) and BD + HFMT (9.09\%). Meals were calculated based on the BD according to the needs of each dog to reach the maintenance requirements established by NRC [18] (Table 1). The $\mathrm{ME}(\mathrm{J} / \mathrm{kg})$ of BD was estimated by the equations proposed by the NRC [18] and the amount of food supplied to the dogs was calculated according to the maintenance energy requirement of adult dogs $\left[\mathrm{ME}=502 \mathrm{~J} \times\right.$ body weight $(\mathrm{kg})^{0.75} /$ day]. The amount of food was divided into two equal portions and provided at 09:00 a.m. and 05:00 p.m. Water consumption was measured individually, and evaporative losses were discounted by an intact drinker located into the room.

\subsection{Apparent Total Tract Digestibility (ATTD) Assay}

\subsubsection{Experimental Design}

The experiment was carried out in a randomized block design consisting of two blocks of 10 days, with three treatments and three dogs per treatment in each block, totaling six replications per treatment. Each period included a five-day adaptation phase (day 1 to day 5) followed by a phase of total collection of feces and urine (day 6 to day 10). At the beginning and at the end of each collection period, a gelatin capsule containing $1000 \mathrm{mg}$ of iron (III) oxide $\left(\mathrm{Fe}_{2} \mathrm{O}_{3}\right)$ was given orally to separate the collection periods. Feces were collected and stored under $-20^{\circ} \mathrm{C}$ until the analysis. Body weights (BW) were obtained in the day 1 and 10.

\subsubsection{Fecal Score Assessment}

During data collection, the fecal score was measured in each defecation according to the following scale: 1 = dry and hard; 2 = well formed, leaves no mark when picked up; 3 = wet start to lose shape, leaving a definite mark when removed; $4=$ most, if not all, shape is lost, weak, viscous consistency and 5 = watery diarrhea [19].

\subsubsection{Urinary Analysis}

During collection, the total volume of urine was measured with the aid of a graduated cylinder and an aliquot was taken daily to measure urine $\mathrm{pH}$ and urine density. Digital $\mathrm{pH}$ meter (Kasvi modelo K39-2014B, São José dos Pinhais, PR, Brazil) previously calibrated with $\mathrm{pH} 7$ and 10 buffer solutions was used to measures $\mathrm{pH}$ and density was measured with a portable refractometer (BEL RPI 89/336, Guangzhou, China).

\subsection{Chemical Analysis}

Stool from each dog was thawed, homogenized, and dried in a forced air oven at $55{ }^{\circ} \mathrm{C}$ for $72 \mathrm{~h}$, according to the recommendations of the Association of Official Analytical Chemists [20]. Feces, feather, and diets were ground through a $1 \mathrm{~mm}$ screen in a Wiley hammer mill (DeLeo Equipamentos Laboratoriais, Porto Alegre, Brazil), and analyzed for dry matter (DM-AOAC 934.01), mineral matter (MM-942.05), organic matter (OM-920.36) ether extract (EE-AOAC 954.02; model 170/3, Fanem, São Paulo, Brazil), crude protein (CP -AOAC 954.01; model TE 036/2, Tecnal, Piracicaba, Brazil), and $100 \mathrm{~mL}$ urine samples were lyophilized for GE analysis following the protocols of the AOAC [20]. The gross energy (GE) of diets and feces were determined using isoperibolic bomb calorimetry (calorimeter, basic Model C2000, Ika ${ }^{\circledR}$-Werke, Staufen, Germany). All analyzes were performed in duplicate 
and repeated when the variation was greater than $1 \%$ for energy and more than $5 \%$ for other analyzes (Tables 1 and 2).

\subsection{Fecal Microbial Count, $\mathrm{pH}$ and Ammonia}

Aliquots of feces were collected during the five days to check the fecal microbial count, $\mathrm{pH}$, and fecal ammonia. The microbial counting methodology was the same used in the feather meal. A digital pH meter was used to measure pH (Kasvi model K39-2014B, Paraná, Brazil) previously calibrated with pH 7 and 10 buffer solutions. The ammonia concentration was determined in $3 \mathrm{~g}$ of feces, which was incubated for $1 \mathrm{~h}$ in a $500 \mathrm{~mL}$ Erlenmeyer, containing $250 \mathrm{~mL}$ of distilled water. Then, 3 drops of octyl alcohol (1-octanol) and $2 \mathrm{~g}$ of magnesium oxide were added to the solution. Then the solution was distilled in a macro-Kjeldahl apparatus and recovered in a flask containing $25 \mathrm{~mL}$ of boric acid. Finally, the ammonia was titrated, using standardized sulfuric acid at $0.1 \mathrm{~N}$. The fecal ammonia concentration was calculated as [21]:

$\mathrm{N}$-ammonia $(\mathrm{g} / \mathrm{kg})=\mathrm{N} \times$ correction radius $\times 17 \times($ blank acid volume $) /$ sample weight $(\mathrm{g})$

The ammonia concentration in the feces was adjusted for fecal DM. Microbial counts were made in feces and BD by microbial counting technique.

\subsection{Feces Collection for Microbiota Identification}

After five days of adaptation to the diet, $10 \mathrm{~g}$ of feces were collected, homogenized aseptically, within $30 \mathrm{~min}$ after defecation. The content was divided into three sterile plastic tubes, sealed with parafilm, and kept in a freezer at $-80^{\circ} \mathrm{C}$ for the fecal microbiota analysis using amplicon sequencing.

DNA Extraction, Amplicon Sequencing and Analysis

Before DNA extraction, $3 \mathrm{~g}$ of feces from each dog in the treatment were mixed and sampled out to perform DNA extraction. Total DNA was extracted using DNeasy PowerSoil Kit (Qiagen) following the manufacturer's instructions. To characterize the prokaryotic population present in samples, fragments of the 16S rRNA gene were amplified using universal primers 515F and 806R [22]. Amplification was performed in a $50 \mu \mathrm{L}$ mixture, consisting of $1.5 \mathrm{mM} \mathrm{MgCl}, 0.2 \mu \mathrm{M}$ of each primer, $0.2 \mathrm{mM}$ of each $\mathrm{dNTP}$, $1 \mathrm{U}$ Platinum Taq DNA polymerase, 1X PCR reaction buffer, and approximately $10 \mathrm{ng}$ of genomic DNA. PCR conditions used were one initial denaturation step at $95{ }^{\circ} \mathrm{C}$ for $3 \mathrm{~min}, 25$ cycles including denaturation for $30 \mathrm{~s}$ at $95^{\circ} \mathrm{C}$, annealing for $1 \mathrm{~min}$ at $52{ }^{\circ} \mathrm{C}$, and extension for $1 \mathrm{~min}$ at $72{ }^{\circ} \mathrm{C}$, with one final extension step for $7 \mathrm{~min}$ at $72{ }^{\circ} \mathrm{C}$. After purifying PCR amplicons using Agencount AMPure Beads (Beckman Coulter, Brea, CA, USA), library construction was performed as described in the Ion Plus Fragment Library from an initial amount of $100 \mathrm{ng}$ of DNA. Since all samples were sequenced in a multiplexed PGM run, barcode sequences were used to identify each sample from the total sequencing output. Amplicon sequencing was conducted on an Ion Torrent PGM System (Thermo Fisher, Waltham, MA, USA) using an Ion 316 chip, following the manufacturer's instructions. Sequences were trimmed to retain only reads longer than $100 \mathrm{bp}$ and high-quality bases (Phred score > 30) using PRINSEQ [23]. Sequences were clustered using UCLUST on QIIME v1.9.1 [24]. OTUs were selected based on 97\% sequence similarity and taxonomic data were achieved through the classification algorithm using the GreenGenes 13.8 [25].

\subsection{Calculation and Statistical Analysis}

Digestible energy (DE; J/kg) of hydrolyzed feather meals were calculated according to the methodology described by Kong and Adeola (17).

$$
\left.\mathrm{ATTD}_{\text {ingredient }}, \%=\left[\mathrm{ATTD}_{\text {test diet }}, \%-(100 \%-\mathrm{X} \%) \times \mathrm{ATTD}_{\mathrm{basal}}, \%\right)\right] / \mathrm{X} \%
$$

where ATTD $_{\text {ingredient }}$ is the ATTD of energy in the test ingredient (\%), ATTD test diet is the ATTD of the energy in the test diet $(\%)$, ATTD basal diet $_{\text {is }}$ the ATTD of the energy in the basal 
diet, and $\mathrm{X}$ is the proportion that the basal diet was replaced by the test ingredient. The data means were analyzed by ANOVA, using Minitab ${ }^{\circledR}$ (2013) and the means compared by the Tukey test $(p<0.05)$. Faecal score values were analyzed using the Kruskal-Wallis non-parametric test $(p<0.05)$.

\section{Results}

The total feather degradation factor was calculated and resulted in 0.45 . Evaluation by electron microscopy revealed differences between processed feather meal and in natura feathers (Figure 1).

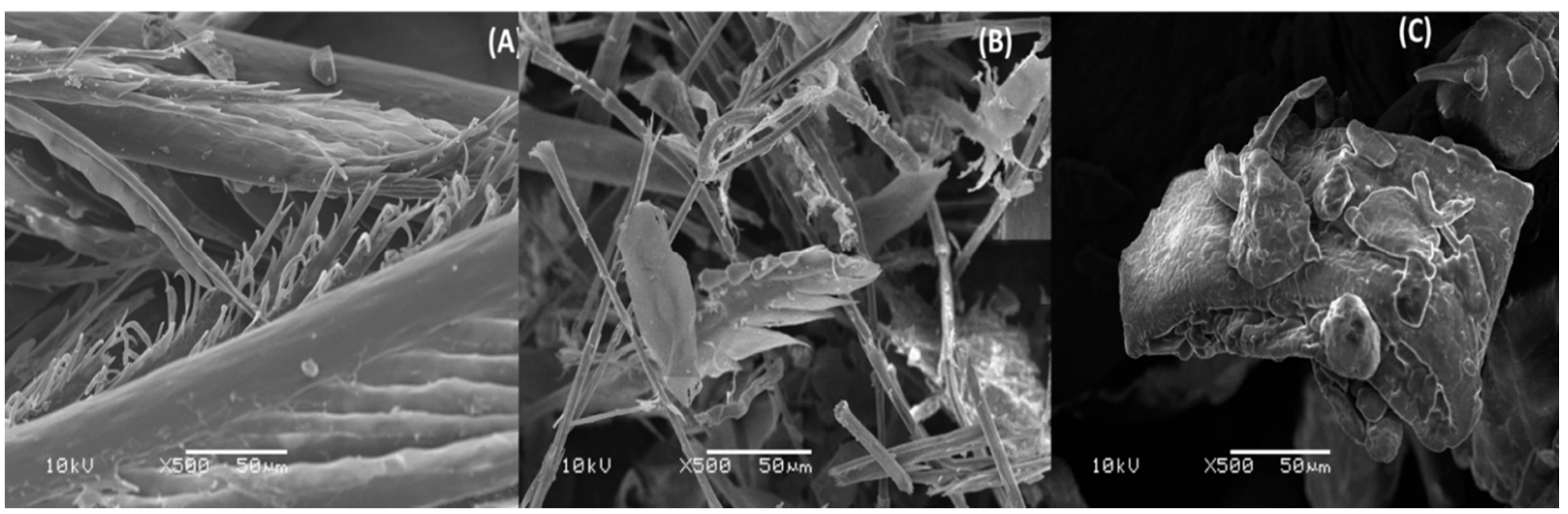

Figure 1. Scanning electron microscopy in natura feather (A), Bacillus subtilis hydrolyzed feather meal (B) and thermal hydrolyzed feather meal (C).

The original feather structure was altered in the meal processed with microorganisms, and small fragments could be observed with recognizable portions of the whole feather. Through thermal processing, the feather structures have become smaller, and the original feather pattern can no longer be recognized with small globular fragments. Analyzes of HFMT reveal similar concentrations of macronutrients with a greater concentration of mineral matter in the HFMBs (Table 2).

The original AA profile of the feathers was modified by bioprocessing (Table 2). The lysine and tryptophan content in HFMBs were about $100 \%$ higher compared to HFMT, but sulfur AAs were reduced. The results of PER were estimated using the AA composition and it resulted in similar values between the ingredients (HFMBs $=2.8$; HFMT $=2.7$ ). Culture in plates permitted to identify the growth of Bacillus spp. in the HFMBs through the observation of typical Bacillus colony. Plates inoculated with feathers and thermally processed feather meal did not show the growth of microorganism.

The tested diets were isoenergetic and isonutritive, except for the protein that varied according to the inclusion of feather meal (Table 1). During the whole experiment, there were no cases of food refusal or episodes of diarrhea, emesis, or any clinical manifestation related to changes in the gastrointestinal tract or another system. During the total tract digestibility test, dogs' body weight did not change $(p>0.05)$ (Table 3$)$. Dogs consumed all the meals, and no leftovers were observed along the entire experimental assay. The consumption of energy and nutrient were similar, except for the consumption of $\mathrm{CP}$, which was higher for treatments with the inclusion of HFMBs and HFMT (Table 3). Water consumption and urinary characteristics, $\mathrm{pH}$, and density were not altered by the inclusion of HFMBs and HFMT ( $p>0.05)$. Fecal characteristics such as fecal score and $\mathrm{pH}$ were not affected by processed feather meal $(p>0.05)$. The total production of feces ( $\mathrm{g} / \mathrm{day})$ was greater in HFMBs treatment (Table 3 ). The ammonia concentration was also affected by the inclusion of the meals and the greatest concentration was observed on inclusion of HFMT $(p<0.05)$. 
Table 3. Nutrient intake, apparent total tract digestibility, fecal and urinary characteristics of dogs fed diets containing 9.09\% feather meal hydrolyzed by Bacillus subtilis and 9.09\% thermally hydrolyzed feather meal.

\begin{tabular}{|c|c|c|c|c|c|}
\hline \multirow{2}{*}{ Items } & \multicolumn{3}{|c|}{ Diets $^{1}$} & \multirow[b]{2}{*}{ SEM $^{2}$} & \multirow[b]{2}{*}{$p$-Value ${ }^{3}$} \\
\hline & BD & BD + HFMBs & BD + HFMT & & \\
\hline \multicolumn{6}{|c|}{ Body weight, kg } \\
\hline Initial & 11.4 & 11.2 & 11.2 & \multirow{2}{*}{0.429} & \multirow{2}{*}{0.984} \\
\hline Final & 11.5 & 11.3 & 11.3 & & \\
\hline \multicolumn{6}{|c|}{ Daily intake, g/day } \\
\hline $\mathrm{DM}$ & 217.5 & 216.4 & 225.3 & 30.22 & 0.845 \\
\hline $\mathrm{OM}$ & 198.5 & 197.8 & 206.2 & 27.6 & 0.828 \\
\hline $\mathrm{CP}$ & $294.5^{b}$ & $367.8^{\mathrm{a}}$ & $381.4^{\mathrm{a}}$ & 47.0 & 0.010 \\
\hline Water consumption, $\mathrm{mL} /$ day & 442.6 & 445 & 439.4 & 101.8 & 0.995 \\
\hline \multicolumn{6}{|c|}{ Energy intake, J/day } \\
\hline $\mathrm{DE}$ & 3820 & 3839 & 4176 & 581,2 & 0.471 \\
\hline $\mathrm{ME}$ & 3550 & 3550 & 3837 & 535.1 & 0.544 \\
\hline \multicolumn{6}{|c|}{ Apparent total tract digestibility, $\%$} \\
\hline DM & 79.89 & 75.46 & 78.61 & 2.422 & 0.013 \\
\hline $\mathrm{OM}$ & $84.09^{\text {a }}$ & $78.72^{b}$ & $82.48^{a}$ & 1.957 & 0.001 \\
\hline $\mathrm{CP}$ & $87.81^{\mathrm{a}}$ & $74.81^{\mathrm{b}}$ & $85.02^{\mathrm{a}}$ & 3.052 & 0.001 \\
\hline Acid hydrolyzed fat & 89.37 & 87.13 & 87.73 & 2.745 & 0.366 \\
\hline Gross Energy & $83.96^{\mathrm{a}}$ & $79.61^{\mathrm{b}}$ & $83.09^{a}$ & 1.907 & 0.005 \\
\hline \multicolumn{6}{|c|}{ Nutritional value of diet, $\mathrm{J} / \mathrm{kg}$} \\
\hline DE analysed & $17,092^{b}$ & $17,184^{\mathrm{b}}$ & $18,079^{a}$ & 401.9 & 0.001 \\
\hline ME estimated ${ }^{4}$ & $15,849^{b}$ & $15.853^{b}$ & $16.573^{a}$ & 381.9 & 0.004 \\
\hline \multicolumn{6}{|c|}{ Urinary and fecal characteristics } \\
\hline Total volume, mL/day & 243.4 & 247.5 & 297.8 & 82.41 & 0.427 \\
\hline $\mathrm{pH}$ urinary & 7.63 & 7.41 & 7.04 & 0.442 & 0.083 \\
\hline Urine density, g/L & 1.033 & 1.028 & 1.033 & 0.005 & 0.204 \\
\hline Urine energy, $\mathrm{J} /$ day & 7.88 & 7.07 & 5.47 & 1.44 & 0.578 \\
\hline Fecal score ${ }^{5}, 1$ to 5 & 2.86 & 2.82 & 2.90 & 0.06 & 0.725 \\
\hline $\mathrm{pH}$ fecal & 6.64 & 6.78 & 6.84 & 0.390 & 0.672 \\
\hline Fecal DM, \% & 36.63 & 35.61 & 34.98 & 1.522 & 0.183 \\
\hline Feces, g/day & $119.65^{b}$ & $148.68^{a}$ & $133.67^{a b}$ & 17.944 & 0.041 \\
\hline Feces, g/d (DM g/day) & $43.56^{b}$ & $52.87^{\mathrm{a}}$ & $46.83^{\mathrm{ab}}$ & 6.115 & 0.05 \\
\hline Amonia $^{6}(\mathrm{DM} \mathrm{g} / \mathrm{kg})$ & $2.090^{\mathrm{b}}$ & $2.658^{a b}$ & $3.377^{a}$ & 0.850 & 0.045 \\
\hline
\end{tabular}

${ }^{1} \mathrm{BD}=$ diet basal; DB + HFMBs = basal diet added by coverage in 9.09\% Bacillus subtilis hydrolyzed feather meal; DB + HFMT = basal diet added by coverage in $9.09 \%$ thermal hydrolyzed feather meal. ${ }^{2}$ Standard error mean. $n=6$ dogs per diet. ${ }^{3}$ Means followed by superscript different letters $(a ; b)$ in the same row differ significantly by Tukey test $(p<0.05) .{ }^{4}$ ME estimated according to the FEDIAF (12). ${ }^{5}$ Fecal score (19). No significant by the Kruskal-Wallis test. ${ }^{6}$ Amonia- $\mathrm{N}(\mathrm{g} / \mathrm{kg})=\mathrm{N} \times$ correction factor $\times 17 \times($ volume of acid - blank)/sample weight $(\mathrm{g})$.

HFMBs showed lower ATTD of energy (DE) compared with HFMT $(p<0.05)$. HFMT showed a greater ATTD of energy of $76 \%$. The DE values were $9196 \mathrm{~J} / \mathrm{kg}$ and $18,589 \mathrm{~J} / \mathrm{kg}$ for HFMBs and HFMT, respectively $(p<0.05)$ (Figure 2). 

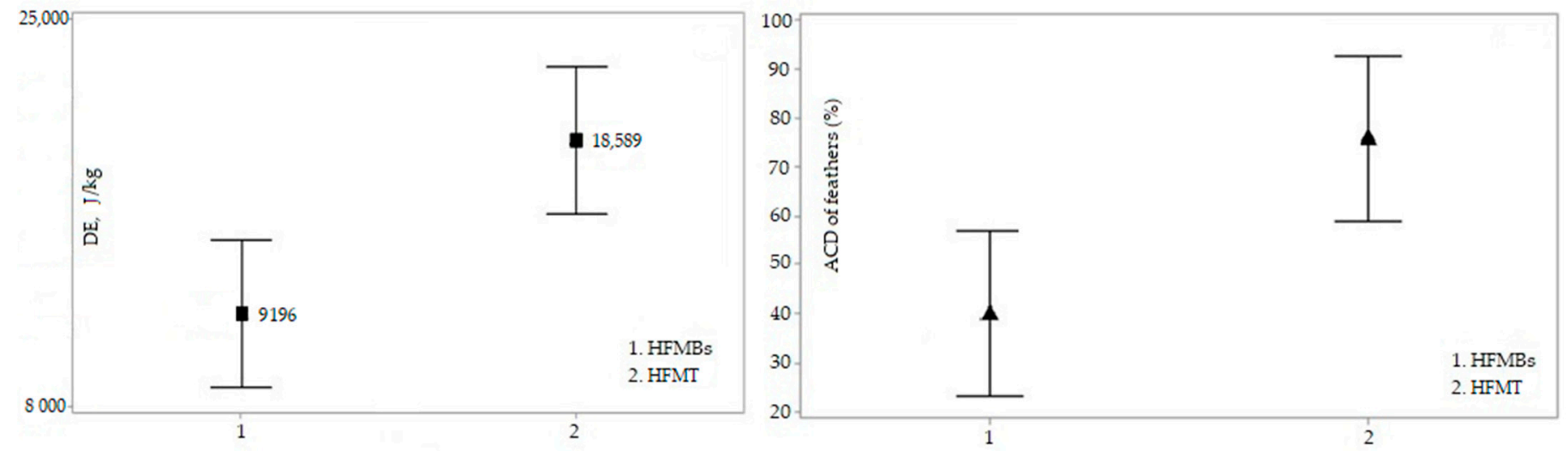

Figure 2. Digestible energy values for HFMBS and HFMT in adult dogs (HFMBS: $9196 \mathrm{~J} / \mathrm{kg}$; HFMT: 18,589 J/kg; $p<0.05$ ). Different means by the Tukey test $5 \%$. Apparent total tract digestibility values for HFMBs and HFMT energy (HFMBs: 40.0; HFMT: 76.0, $p<0.05)$. Different means by the Tukey test $5 \%$.

Bacterial counts were below the detection limit for BD and HFMT diets but reached more than $10^{4} \mathrm{CFU} / \mathrm{g}$ in HFMBs formulation. In feces samples, a greater quantity of typical colonies of Bacillus spp. were observed for dogs that received HFMBs, showing counts ranging from $10^{5}$ to $10^{7} \mathrm{CFU} / \mathrm{g}$ (Table 4).

Table 4. Colony forming units (CFU/g) in the basal diet (BD), diets containing $9.09 \%(w / w)$ feather meal hydrolyzed by Bacillus subtilis (HFMBs), 9.09\% $(w / w)$ thermal hydrolyzed feather meal (HFMT) and feces that consumed the diets.

\begin{tabular}{cc}
\hline Diet & Bacterial Counts (CFU/g) \\
\hline BD & $<10$ \\
HFMT & $<10$ \\
HFMBs & $5.9 \times 10^{4}$ \\
\hline
\end{tabular}

Feces

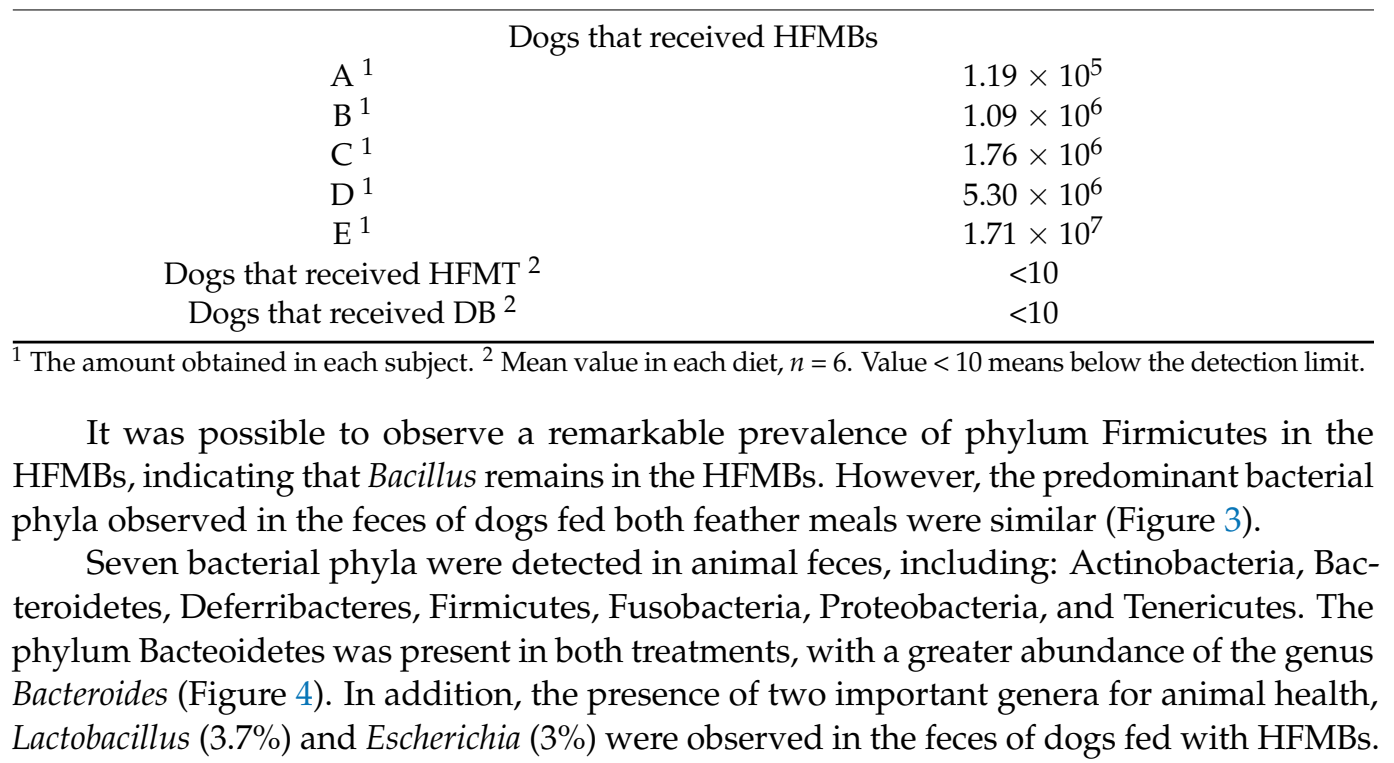




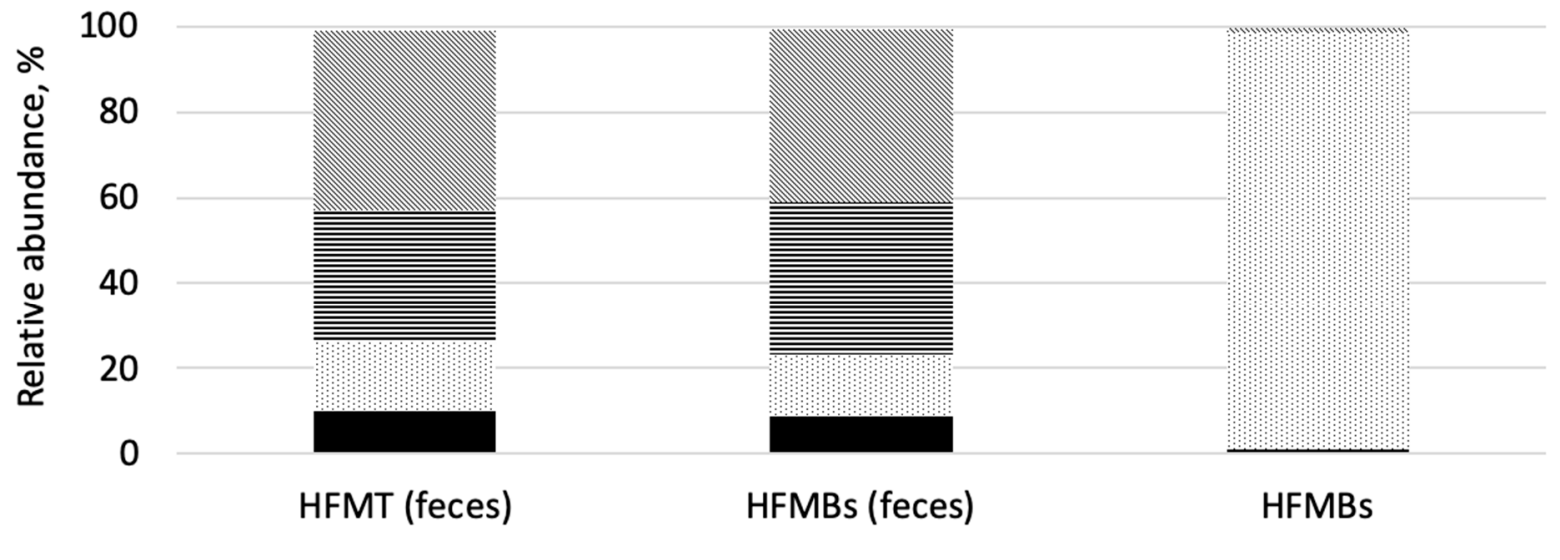

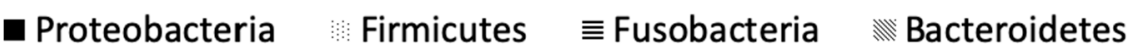

Figure 3. Abundance of Bacteria phyla present in fecal microbiota of dogs consuming diet containing $9.09 \%$ Bacillus subtilis hydrolyzed feather meal (HFMBs), 9.09\% thermally hydrolyzed feather meal (HFMT), and pure Bacillus subtilis hydrolyzed feather meal (HFMBs). Phyla showed in the figure represents more than $99 \%$ of bacteria identified. The other phyla detected are Tenericutes, Verrucomicrobia, Lentisphaerae, Chloroflexi, Deferribacteres, Epsilonbacteraeota, Acidobacteria, and Actinobacteria.

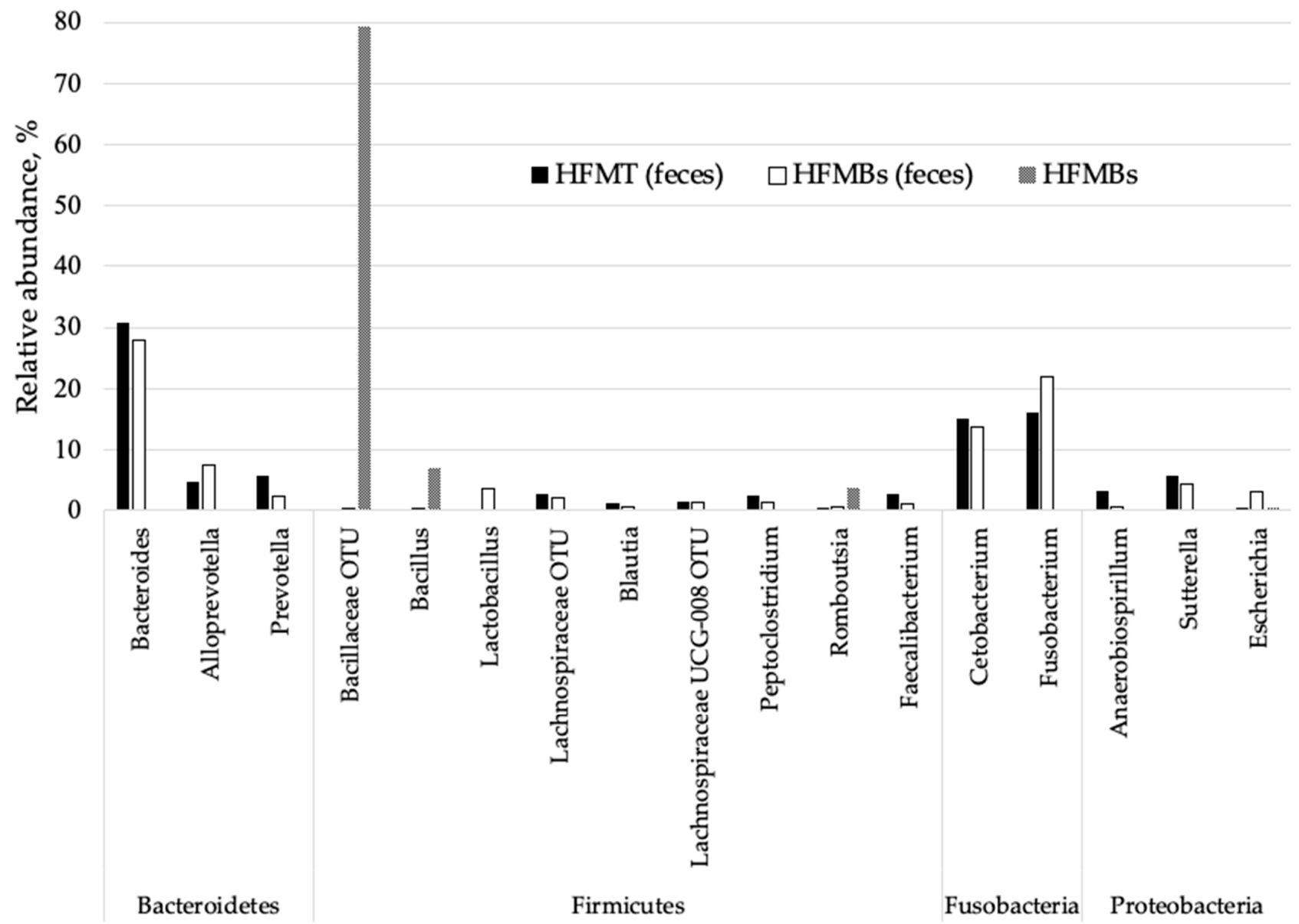

Figure 4. Relative abundance (\%) of bacterial genus present in fecal microbiota of dogs consuming diet containing $9.09 \%$ Bacillus subtilis hydrolyzed feather meal (HFMBs), 9.09\% thermally hydrolyzed feather meal (HFMT), and pure Bacillus subtilis hydrolyzed feather meal (HFMBs). Genus showed in the figure represents more than $90 \%$ of bacteria identified. 


\section{Discussion}

The digestion of feathers by microorganisms has been studied for several years. More specifically, many bacterial strains showed an excellent potential to be used in feather-degrading bioprocesses $[9,24,26-28]$. In vitro tests permitted to establish submerged cultivation protocols containing $2 \%(w / v)$ feathers and reaching complete hydrolysis in $48 \mathrm{~h}[9,29,30]$. In our study, $2 \%(w / v)$ feather was considered too low to produce the amount of hydrolyzed feathers needed to conduct the in vivo ATTD study, once the process yield, in terms of DM, would be very low. To improve the yield, we used $10 \%(w / v)$ feathers In vitro and it worked properly, however, when the incubation was carried out on a larger scale, the degradation factor achieved was 0.45 which is considered lower compared to other studies that evaluated feather hydrolysis In vitro $[9,30]$. However, scanning microscopy analysis have shown some changes in the pattern of the original feathers.

Both methods, microbial and thermal hydrolysis, showed differences in the concentrations of essential AA, such as lysine, methionine, tryptophan, tyrosine, arginine, and phenylalanine, with some reduction in the sulfur AA in HFMBs. Other feather-degrading studies with keratinolytic strains reported similar results, suggesting that the bacterial biomass improved the content of some essential AA such as lysine, histidine and methionine, and reduction in cystine [27,31].

The quality of protein was estimated according to Friedmam [32]. The PER estimates on feathers meal were high and it is an indicative that protein has important amino acids. All protein sources studied (PER $>2.0$ ) were considered a good quality protein. However, protein quality is a measurement of the AA balance that is absorbed and used for growth and other functions. The total tract digestibility indeed counts for protein quality. The hydrolysis by Bacillus spp. tends to improve PER. It may occur due to fermentation process and the microbial biomass formed. In this study, Bacillus spp. remained present and viable in the meal after the hydrolysis process. After hydrolysis, feathers were dried at $65^{\circ} \mathrm{C}$, which may have induced sporulation, arousing interest in the probiotic capacity of this strain [10]. Counting viable bacteria in diets and feces revealed that the HFMBs carried Bacillus spp. only in dogs fed HFMBs, which ones passed through the dogs' gastrointestinal tract and were found in viable form within the fecal content, being then possibly active in the host [11]. The resistance of Bacillus spp. to the conditions of feed processing and digestive tract must bring out the possibility of this strain to have a probiotic function in dogs, similarly to that suggested for broilers [33]. It is known that it depends on several factors, such as dose administered, period of time, method of application in the diet, frequency of feeding with the probiotic, environmental stress factors, and others [34]. But at least, it could be observed the resistance of the Bacillus to the digestive action in dogs.

The inclusion of feather meals improved the consumption of protein once protein in the diets was increased by addition of HFMBs or HFMT. There were no differences in the consumption of the other dietary components. The lowest total tract digestibility coefficients of organic matter, crude protein, and crude energy were found in the diet with HFMBs. Murray et al. [35] assessing animal by-products, processed or not, as ingredients for dog diets, considered that the presence of feathers is one of the factors that could negatively influence the total tract digestibility of poultry by-products. It is assumed that degradation by microorganisms was not as efficient as the thermal process, as the remaining disulfide bridges in the keratin structure impair the use of protein. It has been recognized that the extensive hydrolysis of keratins requires a combination of proteolytic enzymes and adequate redox environment [36]. Thus, it can be hypothesized that disulfide bonds of the HFMBs were less affected, causing the low solubility of the HFMBs, making it difficult for the digestive enzymes of dogs (pepsin and pancreatic enzymes). Previous studies have evaluated feather meal hydrolyzed by thermal treatment in dog food. Cavalari et al. [37] found an ATTD coefficient of GE, DM and CP as 79.8, 76.0 and 82.3\%, respectively. Similar ATTD was found in our study with GE values $=86 \%$, DM $=79 \%$ and $\mathrm{CP}=85 \%$. Pacheco et al. [5], found that feather meal with enzymes included in the thermal hydrolysis process, under lower pressure and temperature, resulted in an improvement in the digestible energy 
compared to feather meal without enzymes $(77 \%, 66 \%$, respectively) and concluded that the enzyme-processed ingredient can be considered a source of protein in adult dog diets. Studies with pigs using thermal processed feather meal have shown that it can be used as a protein ingredient as long as supplemented with synthetic AA [38-40].

The moisture and fecal score were not affected by the treatments in range considered ideal for the score, according to Moxham [19]. Similar results have been reported by Pacheco et al. [5] which included 7 and 15\% of hydrolyzed feather meal in the diets and the dogs produced feces within an appropriate fecal score. Stool production (g/day) was increased by the inclusion of HFMBs (149 $\mathrm{g} /$ day), which differed from the control diet (120 g/day) but showed no significant difference in relation to HFMT (134 g/day) $(p>0.05)$. Pacheco et al. [5], also found higher fecal production for the group of dogs fed $15 \%$ of feather meal processed in the thermal method or processed with addition of enzymes and under lower temperature in relation to the basal diet (222, 209 and $180 \mathrm{~g} /$ day, respectively). As expected, the fecal ammonia content was increased by the inclusion of feather meal, which indicates the presence of the greater amount of undigested protein into the hindgut of dogs fed HFMBs compared to HFMT. This fact represents high availability of protein to the microbiota [41], impacting on fecal characteristics, mainly the concentration of ammoniacal nitrogen in the feces.

The ATTD coefficient value for HFMBs (40\%) found in our study shows that under the conditions used, the bioprocess with B. subtilis was not able to provide the nutrients and energy as the thermal process. Malmann [42], in a study carried out with feathers in the broilers diet, observed that the lowest coefficient of ileal digestibility was found for the feathers hydrolyzed by B. subtilis compared to thermal processed feather meal.

Upon further inspection of the phylum bacteria present in the HFMBs, it was observed that the phylum Firmicutes, genus Bacillus was the most abundant, showing that microorganisms remain in the hydrolyzed feather proteins and are able to colonize in the environment (feathers in nature). Bacillus are able to synthesize several proteolytic enzymes during their growth or sporulation phase [43], however, in our study, Bacillus did not perform this function with requisite efficiency that would significantly improve the digestibility of the ingredient.

Diet is the main factor that modulates the microbial activity in the gastrointestinal tract of dogs. The digesta that reaches the large intestine will determine the microbiota by the amount and type of substrate that it provides [44]. The presence of phyla was similar in the feces of dogs fed diets containing 9.09\% HFMBs and 9.09\% HFMT. Handl et al. [45] analyzed the fecal microbiota of 12 healthy pet dogs and 12 cats and identified that the most abundant bacteria phylum was Firmicutes, followed by Bacteroidetes in dogs and Actinobacteria in cats. Ritchie et al. [46] and Suchodolski et al. [47] constructed 16S rRNA gene clone libraries to characterize the microbiota in chyme samples from various segments of the gastrointestinal tract of healthy dogs and cats. Firmicutes, Bacteroidetes, and Proteobacteria were the most abundant phyla observed. Similar results were observed in this study, with Bacteroidetes being the most abundant phylum in both treatments. Middelbos et al. [48], obtained similar results when fed dogs with or without fiber supplementation $(7.5 \%$ of beet pulp) and observed approximately 129 OTU, with Fusobacteria (23-40\% of readings), Bacteroidetes (31-34\% of readings) and Firmicutes (14-28\% of readings).

It is important to highlight that dogs used in this study had the ideal body condition score 5 out 9 points [49] and fecal score, which is comparable with the microbiota present in lean dogs. Previous research has shown a greater abundance of Firmicutes in obese mice fed Western diets, concomitant decreasing abundance of Bacteroidetes [50,51]. Furthermore, some studies have described that the gut microbiota of obese animals and humans exhibits a higher Firmicutes/Bacteroidetes ratio compared with normal-weight individuals [52].

Studies using cultivation methods revealed that Bacteroides, Clostridium, Lactobacillus, Bifidobacterium, and Enterobacteriaceae are the predominant bacterial groups in the canine and feline intestine [53-55]. However, the most observed genera in the feces of dogs fed $9.09 \%$ HFMBs or 9.09\% HFMT were Bacteroides, Cetobacterium, and Fusobacterium. 
Species from the Bacteroides genus generally inhabit the colon, are chemoheterotrophic and promotes the catabolism of branched chain amino acids [56]. Amino acid metabolism by gut microbiota results in a complex mixture of metabolic end products including among others ammonia, short-chain and branched-chain fatty acids, which are important bacterial metabolites influencing epithelial physiology and modulating the mucosal immune system of the host [57]. Bacteroides spp. help the host by limiting the colonization of pathogens in the gastrointestinal tract [58] through the high production of bacteriocins in the intestine. Bacteriocins are antibacterial substances that reduces bacteria that share the same ecological niche by competition [59].

The presence of the genus Lactobacillus in the feces of dog who received HFMBs was observed, which may be related to a probiotic effect of feather meal hydrolyzed by microorganisms, since bacteria of the genus Bacillus are potential probiotics and may have provided a better environment for gender development. In the same group, the presence of the genus Escherichia was observed, but no cases such as apathy, diarrhea, urinary infection, or any other clinical signs of E. coli strains (pathogenic form) were identified during the study.

Both groups of dogs revealed a highly diverse bacterial microbiota in canine feces, as a result of the interaction of the diet with a gut microbiota. Firmicutes was the most abundant phyla in the HFMBs and the most part of them were represented by Bacillaceae with a presence of Bacillus, which was expected. By the addition of $9.09 \%$ of HFMBs in the diet, Bacillus were not so expressive in the fecal samples and a slightly presence of Lactobacillus was observed. Also, Escherichia was observed in the same treatment, however no negative effects were associated.

\section{Conclusions}

Bacillus subtilis FTC01 has high feather-degrading activity in vitro, but its action was limited when applied to a scale-up prototype using increased feather concentration in the cultivation medium. Thus, the degradation was limited, which generated a less digestible HFMBs. In addition, Bacillus subtilis proved to be resistant and passed through the gastrointestinal tract remaining viable in the feces and may be able to interfere with the dog's microbiota. Improving the technique of feather meal hydrolysis by microorganisms can be a way to produce a rich and available ingredient that can still carry bacteria that may have a probiotic effect.

Author Contributions: Conceptualization, G.S.M., A.P.F.C., A.B., A.d.M.K. and L.T.; methodology, G.S.M., A.P.F.C., P.G.d.S.P., A.B., A.d.M.K. and L.T.; formal analysis, G.S.M., A.P.F.C., L.M. and L.T.; investigation, G.S.M., A.P.F.C., P.G.d.S.P. and L.T.; resources, A.B., A.d.M.K. and L.T.; data curation, G.S.M., A.P.F.C., P.G.d.S.P., L.M., A.d.M.K. and L.T.; writing—original draft, G.S.M., A.P.F.C., P.G.d.S.P., A.B., A.d.M.K. and L.T.; writing-review and editing, G.S.M., A.P.F.C., P.G.d.S.P., L.M., A.B., A.d.M.K. and L.T.; project administration, G.S.M. and L.T.; funding acquisition, A.B., A.d.M.K. and L.T. All authors have read and agreed to the published version of the manuscript.

Funding: This research was funded by Nacional Council for Scientific and Technological Development: 157448/2014-2.

Institutional Review Board Statement: The study was conducted according to the guidelines of the Conselho Nacional de Controle no Uso de Animais (CEUA), and approved by the Ethics Committee of Universidade Federal do Rio Grande do Sul (protocol 20643 in 25 August 2011).

Data Availability Statement: No new data were created or analyzed in this study. Data sharing is not applicable to this article.

Acknowledgments: The authors thank Nacional Council for Scientific and Technological Development for funding and the High-Performance Computing Lab-LAD/PUCRS for allowing access to run the high-throughput amplicon sequencing analyses. We also thank Nacional Council for Scientific and Technological Development for granting the scholarship to Geruza Silveira Machado during her doctorate. 
Conflicts of Interest: The authors declare no conflict of interest.

\section{References}

1. Hollanda, M.A.C. Avaliação Nutriconal da Farinha de Penas Hidrolisada na Alimentação de Frangos de Corte. Master's Thesis, Universidade Federal Rural de Pernambuco, Recife, Brazil, 2009.

2. FAO. World Food and Agriculture—Statistical Yearbook 2020; World Food and Agriculture: Rome, Italy, 2020.

3. Elmayergi, H.H.; Smith, R.E. Influence of growth of Streptomyces fradiae on pepsin-HCl digestibility and methionine content of feather meal. Can. J. Microbiol. 1971, 17, 1067-1072. [CrossRef] [PubMed]

4. Bielorai, R.; Iosif, B.; Neumark, H.; Alumot, E. Low Nutritional Value of Feather-Meal Protein for Chicks. J. Nutr. 1982, 112, 249-254. [CrossRef] [PubMed]

5. Pacheco, G.F.E.; Pezzali, J.G.; Kessler, A.; Trevizan, L. Inclusion of exogenous enzymes to feathers during processing on the digestible energy content of feather meal for adult dogs. Rev. Bras. Zootec. 2016, 45, 288-294. [CrossRef]

6. Cedrola, S.M.L.; de Melo, A.C.N.; Mazotto, A.M.; Lins, U.; Zingali, R.B.; Rosado, A.S.; Peixoto, R.S.; Vermelho, A.B. Keratinases and sulfide from Bacillus subtilis SLC to recycle feather waste. World J. Microbiol. Biotechnol. 2012, 28, 1259-1269. [CrossRef] [PubMed]

7. Nascente, P.S.; Xavier, M.O.; Rosa, C.S.; Souza, L.L.; Meireles, M.C.; Mello, J.R.B. Hipersensibilidade Alimentar em Cães e Gatos. Rev. Clínica Veterinária 2006, 64, 60-66.

8. Harvey, R.; Hall, E. Alergia/intolerância alimentar. Vet. Focus 2009, 19, 36-41. [CrossRef]

9. Ferrareze, P.A.G.; Correa, A.P.F.; Brandelli, A. Purification and characterization of a keratinolytic protease produced by probiotic Bacillus subtilis. Biocatal. Agric. Biotechnol. 2016, 7, 102-109. [CrossRef]

10. Ritter, A.C.; Correa, A.P.F.; Veras, F.F.; Brandelli, A. Characterization of Bacillus subtilis Available as Probiotics. J. Microbiol. Res. 2018, 8, 23-32.

11. Casula, G.; Cutting, S.M. Bacillus Probiotics: Spore Germination in the Gastrointestinal Tract. Appl. Environ. Microbiol. 2002, 68, 2344-2352. [CrossRef] [PubMed]

12. The European Pet Food Industry (FEDIAF). Nutritional Guidelines for Complete and Complementary Pet Food for Cats and Dogs; FEDIAF: Brussels, Belgium, 2021.

13. White, J.A.; Hart, R.J.; Fry, J.C. An evaluation of the Waters Pico-Tag system for the amino-acid analysis of food materials. J. Autom. Chem. 1986, 8, 170-177. [CrossRef] [PubMed]

14. Hagen, S.R.; Frost, B.; Augustin, J. Precolumn phenylisothiocyanate derivatization and liquid chromatography of amino acids in food-PubMed. J. Assoc. Off. Anal. Chem. 1989, 72, 912-916. [PubMed]

15. Lucas, B.; Sotelo, A. Effect of different alkalies, temperature, and hydrolysis times on tryptophan determination of pure proteins and of foods. Anal. Biochem. 1980, 109, 192-197. [CrossRef]

16. Alsmeyer, R.H.; Cunningham, A.E.; Happich, M.L. Equations predict PER from amino acid analysis. Food Technol. 1974, 28 , 34-38.

17. Dewen, L.; Hu, L.; Defa, L.; Fenglai, W. Determination of nutrient digestibility in corn and soybean meal using the direct and substitution methods as well as different basal diets fed to growing pigs. J. Appl. Anim. Res. 2019, 47, $184-188$.

18. NRC. Nutrient Requirements of Dogs and Cats, 1st ed.; National Academies Press: Washington, DC, USA, 2006 ; ISBN 9780309488921.

19. Moxham, G. Waltham feces scoring system-A tool for veterinarians and pet owners: How does your pet rate? Walth. Focus 2001, $11,24-25$.

20. AOAC-Association of Official Analytical Chemists. Official Methods of Analysis of the Association of the Analytical Chemists, 16th ed.; AOAC: Washington, DC, USA, 1995

21. Félix, A.P.; Zanatta, C.P.; Brito, C.B.M.; Sá Fortes, C.M.L.; Oliveira, S.G.; Maiorka, A. Digestibility and metabolizable energy of raw soya manufactured with different processing treatments and fed to adult dogs and puppies. J. Anim. Sci. 2013, 91, $2794-2801$. [CrossRef] [PubMed]

22. Bates, S.T.; Berg-Lyons, D.; Caporaso, J.G.; A Walters, W.; Knight, R.; Fierer, N. Examining the global distribution of dominant archaeal populations in soil. ISME J. 2010, 5, 908-917. [CrossRef]

23. Schmieder, R.; Lim, Y.W.; Rohwer, F.; Edwards, R. TagCleaner: Identification and removal of tag sequences from genomic and metagenomic datasets. BMC Bioinform. 2010, 11, 341. [CrossRef] [PubMed]

24. Caporaso, J.G.; Kuczynski, J.; Stombaugh, J.; Bittinger, K.; Bushman, F.D.; Costello, E.K.; Fierer, N.; Peña, A.G.; Goodrich, J.K.; Gordon, J.I.; et al. QIIME allows analysis of high-throughput community sequencing data. Nat. Methods 2010, 7, 335-336. [CrossRef]

25. DeSantis, T.Z.; Hugenholtz, P.; Larsen, N.; Rojas, M.; Brodie, E.L.; Keller, K.; Huber, T.; Dalevi, D.; Hu, P.; Andersen, G.L. Greengenes, a Chimera-Checked $16 \mathrm{~S}$ rRNA Gene Database and Workbench Compatible with ARB. Appl. Environ. Microbiol. 2016, 71, 672-685. [CrossRef] [PubMed]

26. Riffel, A.; Brandelli, A. Isolation and characterization of a feather-degrading bacterium from the poultry processing industry. $J$. Ind. Microbiol. Biotechnol. 2002, 29, 255-258. [CrossRef]

27. Riffel, A.; Lucas, F.; Heeb, P.; Brandelli, A. Characterization of a new keratinolytic bacterium that completely degrades native feather keratin. Arch. Microbiol. 2003, 179, 258-265. [CrossRef] [PubMed]

28. Daroit, D.J.; Corrêa, A.P.F.; Brandelli, A. Production of keratinolytic proteases through bioconversion of feather meal by the Amazonian bacterium Bacillus sp. P45. Int. Biodeterior. Biodegrad. 2011, 65, 45-51. [CrossRef] 
29. Zaghloul, T.I.; Embaby, A.; Elmahdy, A.R. Biodegradation of chicken feathers waste directed by Bacillus subtilis recombinant cells: Scaling up in a laboratory scale fermentor. Bioresour. Technol. 2011, 102, 2387-2393. [CrossRef] [PubMed]

30. Maciel, J.L.; Werlang, P.O.; Daroit, D.J.; Brandelli, A. Characterization of Protein-Rich Hydrolysates Produced through Microbial Conversion of Waste Feathers. Waste Biomass-Valorization 2017, 8, 1177-1186. [CrossRef]

31. Bertsch, A.; Coello, N. A biotechnological process for treatment and recycling poultry feathers as a feed ingredient. Bioresour. Technol. 2005, 96, 1703-1708. [CrossRef]

32. Friedman, M. Nutritional Value of Proteins from Different Food Sources-A Review. J. Agric. Food Chem. 1996, 44, 6-29. [CrossRef]

33. Fernandez-Alarcon, M.F.; Trottier, N.; Steibel, J.P.; Lunedo, R.; Campos, D.M.B.; Santana, A.M.; Pizauro, J.M.; Furlan, R.L.; Furlan, L.R. Interference of age and supplementation of direct-fed microbial and essential oil in the activity of digestive enzymes and expression of genes related to transport and digestion of carbohydrates and proteins in the small intestine of broilers. Poult. Sci. 2017, 96, 2920-2930. [CrossRef] [PubMed]

34. Guarner, F.; Khan, A.G.; Garisch, J.; Eliakim, R.; Gangl, A.; Thomson, A.; Krabshuis, J.; Le Mair, T.; Kaufmann, P.; De Paula, J.A.; et al. World Gastroenterology Organisation Practice Guideline: Probiotics and Prebiotics-May 2008: Guideline ISouth African Gastroenterology Review. S. Afr. Gastroenterol. Rev. 2008, 6, 14-25.

35. Murray, S.M.; Patil, A.R.; Fahey, G.C.; Merchen, N.R.; Hughes, D.M. Raw and rendered animal by-products as ingredients in dog diets. J. Anim. Sci. 1997, 75, 2497-2505. [CrossRef] [PubMed]

36. Callegaro, K.; Brandelli, A.; Daroit, D.J. Beyond plucking: Feathers bioprocessing into valuable protein hydrolysates. Waste Manag. 2019, 95, 399-415. [CrossRef] [PubMed]

37. Cavalari, A.P.M.; Donzele, J.L.; Viana, J.A.; Abreu, M.L.T.; Oliveira, A.L.S.; Freitas, L.S.; Pereira, A.A.; Carciofi, A.C. Evaluation of nutritive value of energy and protein feeds in adult dog diets. Braz. J. Anim. Sci. 2006, 35, 1985-1991.

38. Chiba, L.; Ivey, H.; Cummins, K.; Gamble, B. Effects of hydrolyzed feather meal as a source of extra dietary nitrogen on growth performance and carcass traits of finisher pigs. Anim. Feed Sci. Technol. 1995, 53, 1-16. [CrossRef]

39. Chiba, L.; Ivey, H.; Cummins, K.; Gamble, B. Hydrolyzed feather meal as a source of amino acids for finisher pigs. Anim. Feed Sci. Technol. 1996, 57, 15-24. [CrossRef]

40. Divakala, K.C.; Chiba, L.I.; Kamalakar, R.B.; Rodning, S.P.; Welles, E.G.; Cummins, K.A.; Swann, J.; Cespedes, F.; Payne, R.L. Amino acid supplementation of hydrolyzed feather meal diets for finisher pigs1,2. J. Anim. Sci. 2009, 87, 1270-1281. [CrossRef]

41. Hesta, M.; Janssens, G.; Debraekeleer, J.; Millet, S.; De Wilde, R. Fecal odor components in dogs: Nondigestible oligosaccharides and resistant starch do not decrease fecal $\mathrm{H}_{2} \mathrm{~S}$ emission. J. Appl. Res. Vet. Med. 2003, 1, 225-232.

42. Mallmann, B.A. Digestibilidade de aa de Penas Submetidos a Diferentes Processos em Dietas de Frango de Corte. Master's Thesis, Universidade Federal do Rio Grande do Sul, Porto Alegre, Brazil, 2015.

43. Vitković, L.; Sadoff, H.L. Purificação da protease extracelular de Bacillus licheniformis e sua inibição pela bacitracina. J. Bact. 1977, 131, 891-896. [CrossRef]

44. Strickling, J.; Harmon, D.; Dawson, K.; Gross, K. Evaluation of oligosaccharide addition to dog diets: Influences on nutrient digestion and microbial populations. Anim. Feed Sci. Technol. 2000, 86, 205-219. [CrossRef]

45. Handl, S.; Dowd, S.E.; Garcia-Mazcorro, J.F.; Steiner, J.M.; Suchodolski, J.S. Massive parallel 16S rRNA gene pyrosequencing reveals highly diverse fecal bacterial and fungal communities in healthy dogs and cats. FEMS Microbiol. Ecol. 2011, 76, 301-310. [CrossRef]

46. Ritchie, L.E.; Steiner, J.M.; Suchodolski, J.S. Assessment of microbial diversity along the feline intestinal tract using $16 \mathrm{~S}$ rRNA gene analysis. FEMS Microbiol. Ecol. 2008, 66, 590-598. [CrossRef]

47. Suchodolski, J.S.; Camacho, J.; Steiner, J.M. Analysis of bacterial diversity in the canine duodenum, jejunum, ileum, and colon by comparative 16S rRNA gene analysis. FEMS Microbiol. Ecol. 2008, 66, 567-578. [CrossRef]

48. Middelbos, I.S.; Boler, B.M.V.; Qu, A.; White, B.A.; Swanson, K.S.; Fahey, G.C., Jr. Phylogenetic Characterization of Fecal Microbial Communities of Dogs Fed Diets with or without Supplemental Dietary Fiber Using 454 Pyrosequencing. PLoS ONE 2010, 5, e9768. [CrossRef] [PubMed]

49. Laflamme, D. Development and validation of a body condition score system for dogs: A clinical tool. Canine Pract. 1997, 22, $10-15$.

50. Ley, R.E.; Bäckhed, F.; Turnbaugh, P.; Lozupone, C.A.; Knight, R.D.; Gordon, J.I. Obesity alters gut microbial ecology. Proc. Natl. Acad. Sci. USA 2005, 102, 11070-11075. [CrossRef]

51. Turnbaugh, P.J.; Bäckhed, F.; Fulton, L.; Gordon, J.I. Diet-Induced Obesity Is Linked to Marked but Reversible Alterations in the Mouse Distal Gut Microbiome. Cell Host Microbe 2008, 3, 213-223. [CrossRef]

52. Magne, F.; Gotteland, M.; Gauthier, L.; Zazueta, A.; Pesoa, S.; Navarrete, P.; Balamurugan, R. The Firmicutes/Bacteroidetes Ratio: A Relevant Marker of Gut Dysbiosis in Obese Patients? Nutrients 2020, 12, 1474. [CrossRef]

53. Benno, Y.; Nakao, H.; Uchida, K.; Mitsuoka, T. Impact of the Advances in Age on the Gastrointestinal Microflora of Beagle Dogs. J. Vet.-Med. Sci. 1992, 54, 703-706. [CrossRef]

54. Johnston, K.L.; Swift, N.C.; Hijfte, M.F.-V.; Rutgers, H.C.; Lamport, A.; Ballavre, O.; Batt, R.M. Comparison of the bacterial flora of the duodenum in healthy cats and cats with signs of gastrointestinal tract disease. J. Am. Vet.-Med. Assoc. 2001, $218,48-51$. [CrossRef]

55. Mentula, S.; Harmoinen, J.; Heikkila, M.; Westermarck, E.; Rautio, M.; Huovinen, P. Comparison between Cultured SmallIntestinal and Fecal Microbiotas in Beagle Dogs. Appl. Environ. Microbiol. 2005, 71, 4169-4175. [CrossRef] [PubMed] 
56. Yoshida, N.; Yamashita, T.; Osone, T.; Hosooka, T.; Shinohara, M.; Kitahama, S.; Sasaki, K.; Sasaki, D.; Yoneshiro, T.; Suzuki, T.; et al. Bacteroides spp. promotes branched-chain amino acid catabolism in brown fat and inhibits obesity. iScience 2021, $24,103342$. [CrossRef]

57. Neis, E.P.J.G.; DeJong, C.H.C.; Rensen, S.S. The Role of Microbial Amino Acid Metabolism in Host Metabolism. Nutrients 2015, 7, 2930-2946. [CrossRef] [PubMed]

58. Gilmore, M.S. Microbiology: The Thin Line between Gut Commensal and Pathogen. Science 2003, 299, 1999-2002. [CrossRef] [PubMed]

59. Wexler, H.M. Bacteroides: The Good, the Bad, and the Nitty-Gritty. Clin. Microbiol. Rev. 2007, 20, 593-621. [CrossRef] [PubMed] 